\title{
PROTEIN NUTRITION AND AGING
}

\author{
Itsiro NaKagawa, Atsuko SaSAKI, Masatoshi KaJimoto, \\ Tomitaro FuKuYAMA, and Emiko YAMADA ${ }^{1}$ \\ Department of Nutrition and Biochemistry, \\ Institute of Public Health, Tokyo
}

(Received January 29, 1975)

\begin{abstract}
Summary Twenty-four female rats consisting of 6 sets of litters were used for the experiment. After weaning, rats were divided into 4 groups and fed with 10,18, 27 and $36 \%$ casein diet. Effect of protein nutrition on aging was examined from the anthropometric and biochemical viewpoint. The difference of growth in body weight, and that of the urinary excretion of creatinine and 17-ketosteroids observed in the early period of growing disappeared by the end of growth period. From 1 year after birth, serum alkaline phosphatase activity and serum cholesterol were also measured. However, effect of protein nutrition on these parameters was not clear due to the scatter of data. The difference in diet did not affect life span in the present experiments, but the effect of the variance of litters on it seemed to be significant between the rats fed $18 \%$ casein diet and those fed $10 \%$ casein diet. Rats fed high-protein diet had a great number of lesions in the kidney and hypophysis, and often an incidence of tumors.
\end{abstract}

There are many papers reporting the relationship between nutrition and aging. According to Ross (1), when the age-associated enzyme activity patterns were modified by dietary means; there were corresponding modifications in life span. With long-term caloric restriction, the levels of any of the biochemical constituents as well as of cell and animal size were more like that of a young rat, and the longest life span was obtained. In previous papers $(2,3)$, we also reported studies on the effect of protein nutrition on growth and life span in the rat. From the anthropometric and biochemical viewpoint, high-protein diet accelerated growth in tail length and body weight, and increased the excretion of metabolites having relation to growth in the early period of growing. However, the differences in these parameters among the groups fed high- or low-protein diet disappeared at the end of growth period. In the present experiment, the effect of protein nutrition on the aging after the end of growth period was examined in rats, with respect to animal size, serum alkaline phosphatase and cholesterol, and urinary excretion

${ }^{1}$ 中川一郎, 佐々木敦子, 梶本雅俊, 福山富太郎, 山田恵美子 
of creatinine and 17-ketosteroids. In addition, the effect of protein nutrition on the life span was examined. Autopsies were performed on all the animals after death to find whether or not any gross pathological conditions had occurred in the organs.

\section{EXPERIMENTAL PROCEDURES}

Twenty-four rats consisting of 6 sets of litters of Donryu strain were used. The rats were fed an $18 \%$ casein diet for 1 week after weaning, and then were separated into four groups. Littermates were evenly distributed among the different groups. The composition of diets fed to each group is shown in Table 1. Semi-pair feeding was carried out; the rat consuming the least food (except when the rat became moribund), when all rats in all groups were considered, was determined, and other rats were limited to the amount consumed by that rat or sometimes 1 or $2 \mathrm{~g}$ more than that amount. Therefore, rats were maintained restrict food intake, and the daily allotment of diet was almost completely consumed. Tail length and body weight were measured at weekly intervals until the end of growth period, and then only body weight was measured. Determination of urinary creatinine and 17-ketosteroids was carried out from the time of weaning, and that of serum cholesterol and alkaline phosphatase was carried out from 1 year after birth. These determinations were made according to the following methods, urinary creatinine by Peters (4), 17-ketosteroids by a modification of the Zimmermann reaction method (5), serum alkaline phosphatase activity by that of BESSEY et al. (6), and cholesterol by a modification of Zak-Henry's method (7).

Table 1. Composition of experimental diets.

\begin{tabular}{|c|c|c|c|c|}
\hline & Group 1 & Group 2 & Group 3 & Group 4 \\
\hline & \multicolumn{4}{|c|}{$g / 100 \mathrm{~g}$} \\
\hline Casein & 18 & 10 & 27 & 36 \\
\hline Corn oil & 10 & 10 & 10 & 10 \\
\hline Cornstarch & 67 & 75 & 58 & 49 \\
\hline Salt mixture ${ }^{1}$ & 5 & 5 & 5 & 5 \\
\hline \multicolumn{5}{|l|}{ Vitamin mixture $^{2}$} \\
\hline \multicolumn{5}{|c|}{$\begin{array}{l}{ }^{1} \text { Composition: (mg/100 g diet) } \mathrm{NaCl}, 1253 ; \mathrm{KI}, 0.025 ; \mathrm{KH}_{2} \mathrm{PO}_{4}, 1715.5 ; \mathrm{CaHPO}_{4} \cdot \\
2 \mathrm{H}_{2} \mathrm{O}, 21.5 ; \mathrm{CaCO}_{3}, 1464.5 ; \mathrm{MgSO}_{4} \cdot 7 \mathrm{H}_{2} \mathrm{O}, 499 ; \mathrm{FeC}_{6} \mathrm{H}_{5} \mathrm{O}_{7} \cdot 6 \mathrm{H}_{2} \mathrm{O}, 31.15 ; \mathrm{CuSO}_{4} \cdot \\
5 \mathrm{H}_{2} \mathrm{O}, 7.80 ; \mathrm{ZnCl}_{2}, 1.00 ; \mathrm{MnSO}_{4} \cdot \mathrm{H}_{2} \mathrm{O}, 6.05 ;\left(\mathrm{NH}_{4}\right)_{6} \mathrm{Mo}_{7} \mathrm{O}_{2} \cdot 4 \mathrm{H}_{2} \mathrm{O}, 0.125 \text {. } \\
{ }^{2} \text { Composition: (mg } / 100 \mathrm{~g} \text { diet) thiamin, } 0.5 ; \text { riboflavin, } 0.8 ; \text { pyridoxine, } 0.5 ; \text { nicotinic } \\
\text { acid, 4.0; } p \text {-Ca-Pantothenate, 4.0; folic acid, 0.4; cyanocobalamin, } 0.003 ; \text { biotin, } \\
\text { 0.04; myoinositol, } 10 ; p \text {-amino-benzoic acid 10; choline, 200; retinol, 1000; ergocal- } \\
\text { ciferol, } 100 \mathrm{IU} ; \alpha \text {-tocopherol, } 4 \text {; menaquinone, 0.5. }\end{array}$} \\
\hline
\end{tabular}

\section{RESULT AND DISCUSSION}

Tail length and body weight of rats are shown in Fig. 1. Growth in tail length and body weight of rats fed $10 \%$ casein diet were less than those of rats fed a 


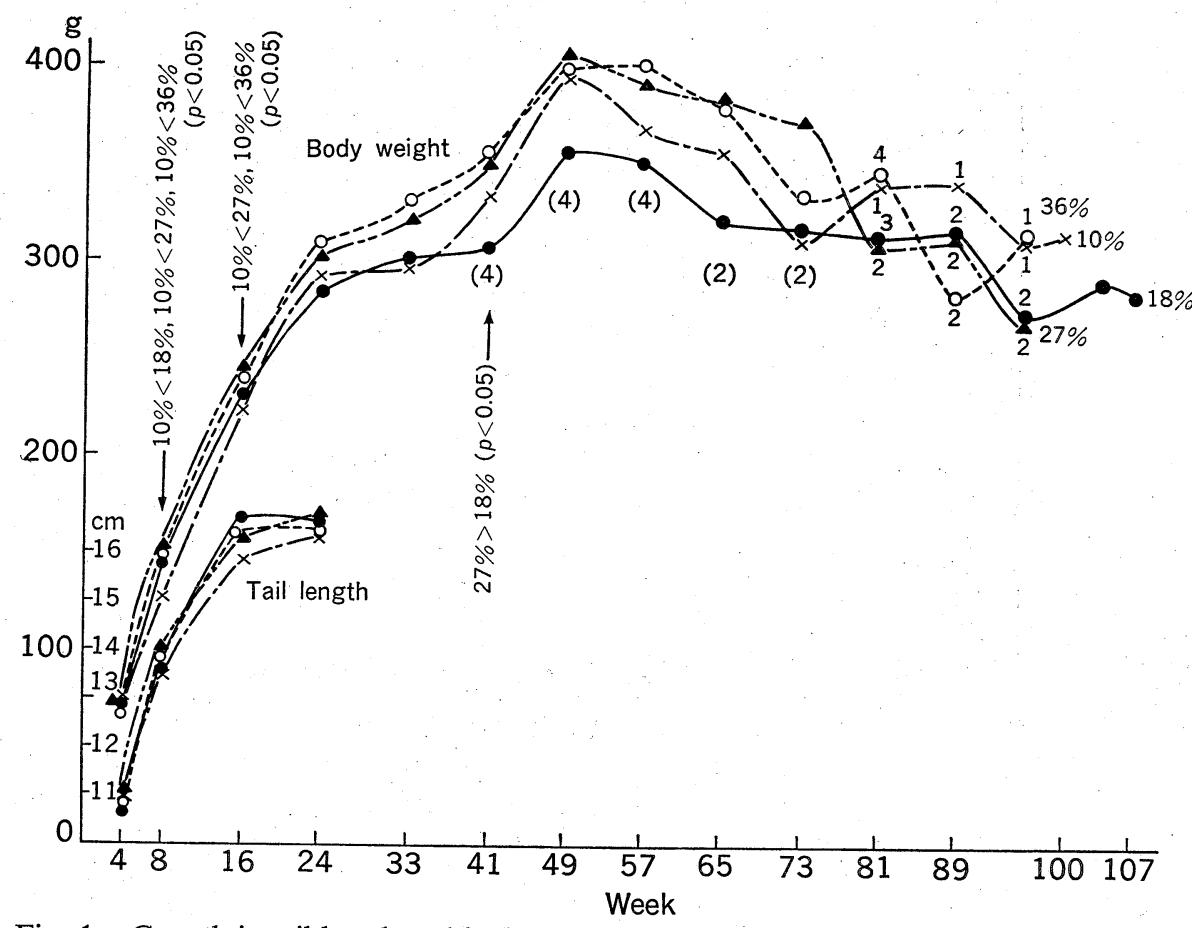

Fig. 1. Growth in tail length and body weight. Numbers in parentheses indicate numbers of litters, each consists of 4 rats. Numbers without parentheses indicate numbers of rats. $\times---\times, 10 \%$;

A, $27 \%$; ○---, $36 \%$.

Table 2. Serum alkaline phosphatase activity.

\begin{tabular}{|c|c|c|c|c|}
\hline $\begin{array}{c}\text { Weeks } \\
\text { after birth }\end{array}$ & $\begin{array}{l}10 \% \\
\text { casein }\end{array}$ & $18 \%$ & $27 \%$ & $36 \%$ \\
\hline & \multicolumn{4}{|c|}{$p$-nitrophenyl phosphate units } \\
\hline $52(4)$ & 2.04 & 2.33 & 2.83 & 3.21 \\
\hline 49 (2) & 4.68 & 3.10 & 7.19 & 4.26 \\
\hline
\end{tabular}

Table 3. Serum cholesterin.

\begin{tabular}{cccccc}
\hline $\begin{array}{c}\text { Weeks } \\
\text { after birth }\end{array}$ & $\begin{array}{r}10 \% \\
\text { casein }\end{array}$ & $18 \%$ & $27 \%$ & $36 \%$ \\
\hline $52(4)$ & 111 & 142 & $\mathrm{mg} / \mathrm{dl}$ & 133 & 123 \\
$69(2)$ & 85 & 114 & 106 & 129 \\
\hline
\end{tabular}

Numbers in parentheses indicate numbers of litters.

high-protein diet in early period of growth, especially 7 to 16 weeks after birth $(p<0.05)$, but the difference disappeared by the end of growth, as reported in previous papers $(2,3)$. The reason for significant difference of body weight between rats fed $18 \%$ casein diet and those fed $27 \%$ casein diet at the 41 st week is 


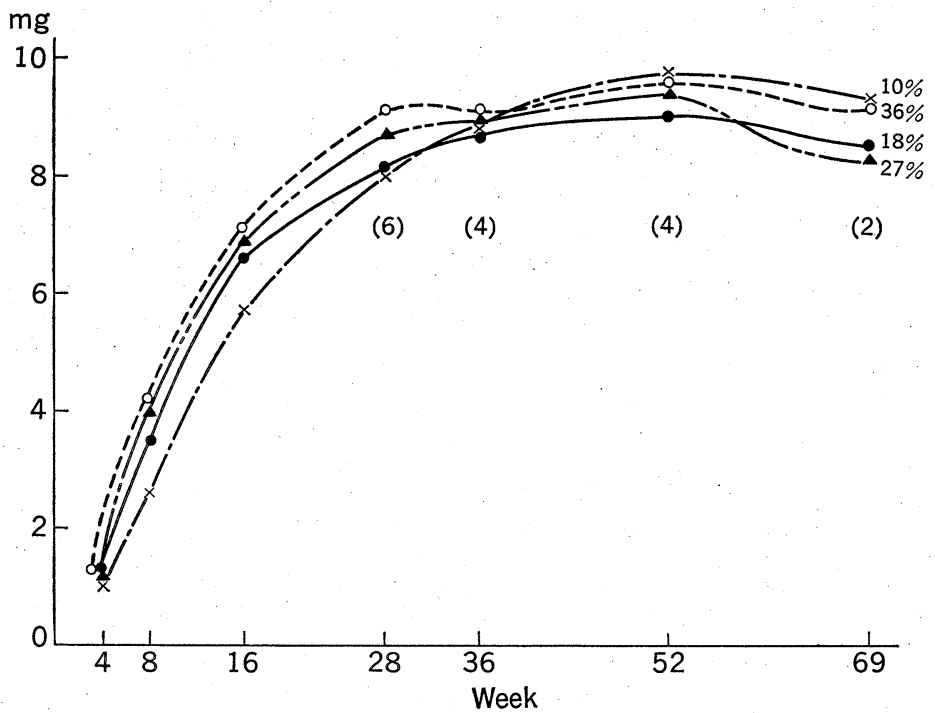

Fig. 2. 24-hr urinary excretion of creatinine. $\quad x---\times, 10 \% ; \bullet-\bullet, 18 \% ; \mathbf{\Lambda}---\mathbf{\Lambda}, 27 \%$; ○--- $36 \%$.

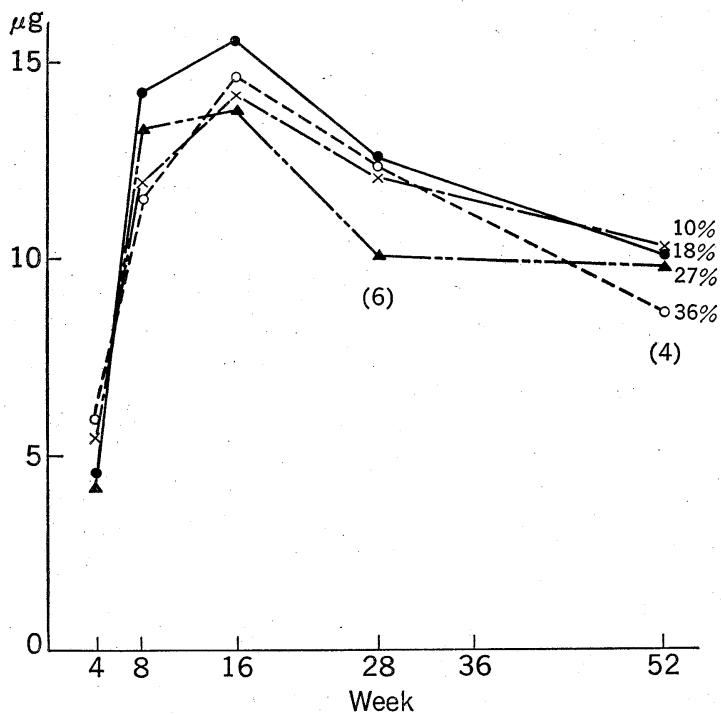

Fig. 3. 24-hr urinary excretion of $17-$ ketosteroids. $\times---\times, 10 \%$; $27 \%$; ○---, $36 \%$. 
unknown. After 1.5 years, body weight decreased in all the rats.

Increase in urinary excretion of creatinine and 17-ketosteroids in the early period of growth seemed to be slowed in the rats fed $10 \%$ casein diet compared with that of the others. After 1 year, differences were not seen among 4 groups due to the scatter of data (Figs. 2 and 3). However, excretion of creatinine in the rats fed $10 \%$ casein diet seemed to increase continually, though to a slight degree. Excretion of 17-ketosteroids tended to decrease in all the rats, especially in those fed $36 \%$ casein diet. Serum alkaline phosphatase activity seemed rather to increase, and serum cholesterol level tended to decrease with aging (Tables 2 and 3 ), but apparent conclusions could not be drawn owing to the small number of rats and scatter of the data.

The effect of difference in diet or variance of litters on life span was statistically examined (two-way classification method) (Table 4). Both the difference in diet and variance of litters did not affect life span among the four groups fed with $10,18,27$ and $36 \%$ casein diet, but the effect of the variance of litters on life span seemed to be significant between the rats fed $10 \%$ casein and those fed $18 \%$ casein $\operatorname{diet}(0.1<p<0.05)$.

Lesions observed at death were less in the lungs of rats fed $10 \%$ casein diet, perhaps owing to greater number of death in rats during earlier part of life (about one year after birth) compared with the rats in other groups. Lesions in lungs are

Table 4. Life span of rats grouped according to diet and littermates.

\begin{tabular}{|c|c|c|c|c|c|}
\hline $\begin{array}{l}\text { No. of } \\
\text { litter }\end{array}$ & $10 \%$ & $18 \%$ & $27 \%$ & $36 \%$ & $\begin{array}{c}\text { Average } \\
\text { (littermates) }\end{array}$ \\
\hline & \multicolumn{4}{|c|}{ days } & days \\
\hline 1 & 712 & 539 & 673 & 565 & $622 \pm 41.7$ \\
\hline 2 & 291 & 256 & 487 & 615 & $412 \pm 84.6$ \\
\hline 3 & 242 & 435 & 558 & 679 & $479 \pm 93.3$ \\
\hline 4 & 505 & 679 & 527 & 417 & $532 \pm 54.5$ \\
\hline 5 & 527 & 750 & 512 & 628 & $604 \pm 55.0$ \\
\hline 6 & 403 & 623 & 677 & 571 & $569 \pm 59.3$ \\
\hline Diet & 447 & 547 & 572 & 579 & \\
\hline average & \pm 70.3 & \pm 73.5 & \pm 33.8 & \pm 36.6 & \\
\hline
\end{tabular}

1 The values are means \pm SEM.

Table 5. Effect of dietary protein level on total numbers of lesions observed macroscopically in organs of rats.

\begin{tabular}{|c|c|c|c|c|c|c|c|c|c|c|}
\hline $\begin{array}{l}\text { Organs } \\
\text { Diets }\end{array}$ & Liver & Spleen & Kidney & Heart & Lung & $\begin{array}{l}\text { Diges- } \\
\text { tive } \\
\text { organs }\end{array}$ & $\begin{array}{l}\text { Repro- } \\
\text { ductive } \\
\text { organs }\end{array}$ & $\begin{array}{l}\text { Hypo- } \\
\text { physis }\end{array}$ & $\begin{array}{l}\text { Lym- } \\
\text { phoid } \\
\text { organs }\end{array}$ & Tumor \\
\hline $10 \%$ casein & $0(0)$ & $2(33)$ & $3(50)$ & $0(0)$ & $2(33)$ & $1(17)$ & $3(50)$ & $2(33)$ & $2(33)$ & $0(0)$ \\
\hline $18 \%$ casein & $1(17)$ & $1(17)$ & $3(50)$ & $0(0)$ & $4(67)$ & $2(33)$ & $1(17)$ & $4(67)$ & $1(17)$ & $1(17)$ \\
\hline $27 \%$ casein & $0(0)$ & $0(0)$ & $1(17)$ & $0(0)$ & $5(83)$ & $2(33)$ & $0(0)$ & $4(67)$ & $1(17)$ & $0(0)$ \\
\hline $36 \%$ casein & $1(17)$ & $2(33)$ & $4(67)$ & $0(0)$ & $4(67)$ & $1(17)$ & $1(17)$ & $5(83)$ & $1(17)$ & $2(33)$ \\
\hline
\end{tabular}

Numbers in parenthesés indicate percentage of cases. 
always observed in older rats. On the other hand, rats fed $36 \%$ casein diet had a greater number of lesions in the kidney and hypophysis but not significant. Especially, the incidence of malignant tumor in rats fed $36 \%$ casein diet was higher than that in other groups (Table 5). Concerning this interesting fact, it is expected to present a report in future, after examining the histological findings.

\section{REFERENCES}

1) Ross, M. H., J. Nutr., 97, 565 (1969).

2) Nakagawa, I. and Masana, Y., J. Nutr., 101, 613 (1971).

3) Nakagawa, I., Sasaki, A., Kajimoto, M., Fukuyama, T., Suzuki, T., and Yamada, M., J. Nutr., 104, 1576 (1974).

4) Peters, J. H., J. Biol. Chem., 146, 179 (1942).

5) Kanbegawa, A., Showa igakukai zassi, 20, 1 (1960).

6) Bessey, O. A., Lowry, O. H., and Brock, M. J., J. Biol. Chem., 164, 321 (1946).

7) Niwa, M., Kitamura, M., and SaIto, M., Rynsho kagaku bunseki, III, Tokyo Kagaku Dojin, p. 72-78 (1969). 